\title{
ANALISIS KARYA GAMBAR BENTUK SISWA KELAS VII SMP NEGERI 1 SIMANGUMBAN BERDASARKAN PRINSIP-PRINSIP SENI RUPA
}

\author{
Maddina Nainggolan ${ }^{*}$, Brisman Silaban ${ }^{2 *}$, Adek Cerah Kurnia Azis ${ }^{3 *}$ \\ Program Studi Pendidikan Seni Rupa Jurusan Seni Rupa Fakultas Bahasa dan Seni \\ Universitas Negeri Medan \\ Jl. Willem Iskandar Pasar V Medan Estate, Kec, Percut Sei Tuan, Kab. Deli Serdang, Kode Pos 20371 \\ Sumatera Utara. Indonesia \\ Email: maddina.nainggolan986@gmail.com
}

\begin{abstract}
Abstrak
Penelitian ini bertujuan untuk mengetahui hasil karya siswa yaitu dalam menggambar bentuk siswa kelas VII SMP Negeri 1 Simangumban berdasarkan prinsip-prinsip seni rupa. Objek yang yang digambar adalah botol dan gelas. Adapun populasi dalam penelitian ini yaitu seluruh hasil karya gambar bentuk siswa kelas VII SMP Negeri 1 Simangumban yang berjumlah 124 karya. dan sampelnya yaitu 30 karya dengan menggunakan teknik Random Sampling. Penelitian ini menggunakan metode deskriptif kualitatif dengan mengetahui bagaimana hasil karya gambar bentuk siswa kelas VII di SMP Negeri 1 Simangumban terlebih dahulu, mendeskripsikan gambaran yang diteliti dan dinilai berdasarkan prinsip-prinsip seni rupa yang telah ditentukan.Hasil temuan penelitian ini menunjukkan bahwa secara keseluruhan karya yang dihasilkan berdasarkan prinsip-prinsip seni rupa memiliki kualitas yang cukup dengan nilai rata-rata $=62,13$. Secara terperinci, nilai rata-rata berdasarkan kelima prinsip-prinsip seni rupa sebagai berikut: prinsip kesatuan $=63,71$, prinsip proporsi $=65$, prinsip komposisi $=64$, Prinsip keseimbangan $=59,22$, dan prinsip terang gelap $=$ 57,18 .
\end{abstract}

Kata Kunci: karya gambar bentuk, prinsip-prinsip seni rupa.

\begin{abstract}
This study aims to find out the results of students' work, namely in drawing the form of class VII students of SMP Negeri 1 Simangumban based on the principles of fine arts. The objects that are drawn are bottles and glasses. The population in this study is all the drawings of students in class VII of SMP Negeri 1 Simangumban, totaling 124 works. and the samples are 30 works using the Random Sampling technique. This study uses descriptive qualitative method by knowing how the results of the work of the VII grade students in SMP Negeri 1 Simangumban first, describe the picture that is researched and assessed based on predetermined art principles. The findings of this study indicate that the overall work produced based on the principles of fine art has sufficient quality with an average value $=62.13$. In detail, the average value is based on the five principles of art as follows: principle of unity $=63.71$, principle of proportion $=65$, principle of composition $=64$, principle of balance $=59.22$, and principle of lightness $=57.18$.
\end{abstract}

Keywords: image form, principles of fine art.

\section{PENDAHULUAN}

Pelajaran seni rupa di sekolah umum, pada dasarnya diarahkan untuk menumbuh kembangkan kepekaan rasa, serta memiliki daya cipta, sehinga terbentuk kesadaran terhadap nilai-nilai seni budaya. Kemampuan ini dapat tumbuh kembang, bila dilakukan serangkaian kegiatan pengamatan, penilaian, analisis dan penghargaan terhadap karya seni, baik di dalam kelas maupun di luar kelas. Salah satu kegiatan yang disebutkan di atas adalah analisis. (Mahmud 2011 : 189) menjelaskan: "Analisis dalam penelitian merupakan bagian penting dalam proses penelitian karena dengan analisis inilah, data yang ada akan tampak manfaatnya, terutama dalam memecahkan masalah penelitian dengan mencapai tujuan akhir penelitian".

Seni rupa merupakan mata pelajaran yang ada didalam kurikulum sekolah menengah pertama (SMP) dengan waktu 2 x 40 menit yang di dalam pelaksanaannya disesuaikan dengan situaisi dan kondisi sekolah masing-masing. Pelajaran seni rupa merupakan hakikatnya bukan sekedar materi ajar yang bersifat keterampilan belaka, tetapi merupakan wahana 


\section{Gorga Jurnal Seni Rupa \\ Volume 07 Nomor 02 \\ p-ISSN: 2301-5942 | e-ISSN: 2580-2380}

pengembangan kreativitas, budi dan kepekaan terhadap keindahan.

Materi yang disampaikan dalam bidang seni rupa meliputi pengetahuan, keterampilan, dan nilai dalam menghasilkan beragam karya seni. Misalnya, lukisan, patung, ukiran dan cetak. Materi-materi yang diberikan akan mengantarkan siswa untuk pengalaman yang estetik dalam bentuk kegiatan mengappresiasi dan berekspresi/berkreasi karya seni rupa.

Salah satu materi dalam pelajaran seni rupa di jenjang SMP yaitu menggambar bentuk, mengambar bentuk adalah suatu kegiatan memindahkan objek yamg dilihat langsung, ke atas bidang gambar dengan lebih mengutamakan kemiripan terhadap model tersebut. Dalam menggambar bentuk diperlukan prinsip-prinsip dalam seni rupa yang diantaranya yaitu: kesatuan, proporsi, komposisi, keseimbangan, dan gelap terang.

Namun pada kenyataannya siswa kurang memahami dalam pembelajaran menggambar bentuk, berdasarkan prinsip-prinsip seni rupa, sehingga dilihat dari hasil karya siswa kelas VII.1 SMP N. 1 Simangumban belum semua mampu memenuhi indikator pencapaian gambar bentuk.

Kegiatan yang dilakukan untuk mengetahui kekurang mampuan siswa dalam menggambar bentuk berdasarkan prinsip-prinsip seni rupa diperoleh dari proses analisis, yaitu adanya kegiatan memeriksa, menyelidiki dan membahas masalah yang dianggap penting untuk memecahkan suatu tujuan tertentu.

Berdasarkan hasil observasi penulis dengan guru mata pelajaran seni seni budaya SMP N. 1 Simangumban menyimpulkan bahwa siswa mengalami kesulitan dalam menggambar bentuk berdasarkan prinsipprinsip seni rupa. Kesulitan yang terjadi antara lain: bentuk gambar objek tidak tepat seperti gambar objek sebenarnya, kurang tepat, terkadang kesan yang ditimbulkan tidak proporsional, terlalu pendek atau terlalu tinggi, terlalu kurus atau terlalu gemuk.

\section{KAJIAN TEORI}

\section{Analisis}

kamus oxford, (2010 : 46) analisis adalah : the detail study or examination or something in orderto understand mere abaout it. "studi rinci atau pemeriksaan sesuatu untuk memahami lebih lanjut tentang hal itu'.

Kemudian menurut (Mahmud 2011 : 189) menjelaskan: "Analisis dalam penelitian merupakan bagian penting dalam proses penelitian karena dengan analisis inilah, data yang ada akan tampak manfaatnya, terutama dalam memecahkan masalah penelitian dengan mencapai tujuan akhir penelitian”.

Berdasarkan penjelasan di atas dapat disimpulkan bahwaanalisis adalah suatu cara memeriksa, menyelidiki dan membahas masalah, peristiwa atau hubungan antara unsur dalam keadaan yang benar dengan cara menemukan suatu yang dianggap penting dalam bentuk yang nyata/fakta untuk memecahkan tujuan akhir penelitian.

\section{Perkembangan Seni Rupa Anak}

Menurut (Masganti 2017: 3) perkembangan adalah pola yang dimulai sejak masa konsepsi dan berlajut sepanjang kehidupan. pada perkembangan seni rupa anak, terdapat beberapa tingkat perkembangan yang dapat digunakan dan ditentukan pola pembinaannya secara tepat. Gambar anak sesuai dengan tingkat pengamatan yang relatif sederhana.Pengamatan anak masih belum tampak jelas bagian-bagiannya secara terinci. Yang tampak pada karya seni rupa anak hanya beberapa bagian kecil yang menarik perhatian, terutama yang menyentuh perasaan dan keinginannya.

\section{Pengertian Karya}

Kamus Besar Bahasa Indonesia, (2014 : 50) menjelaskan bahwa : "karya adalah ciptaan yang dapat menimbulkan rasa indah bagi orang melihat, mendengar atau merasakan”.

Sedangkan menurut kamus Oxford, (2010 : 344) menjelaskan bahwa karya adalah : the act or process of making something that is new, or of causing something toexist that did not exist before. "Tindakan atau proses pembuatan sesuatu yang baru, atau menyebabkan sesuatu yang tidak ada sebelumnya".

\section{Gambar dan Menggambar}

Menurut (Sembiring 2014 : 25) menjelaskan: "gambar dalam bahasa Inggris disebut Drawing, adalah cabang seni rupa dua dimensional yang produk akhirnya berupa gambar". Sedangkan menurut Yuswanti, menjelaskan bahwa "gambar adalah sesuatu yang diwujudkan secara visual dalam bentuk dua dimensi sebagai curahan atau pikiran".

Menurut (Pamandhi 2017 : 8.39) menjelaskan "menggambar adalah memindahkan objek dengan media dua dimensi dengan mengambil objek yang berupa benda-benda disekelilingnya dan digambarkan langsung berbentuk realistis". 


\section{Gorga Jurnal Seni Rupa \\ Volume 07 Nomor 02 \\ p-ISSN: 2301-5942 | e-ISSN: 2580-2380}

Sedangkan Menurut (Simblet 2014 : 6) menjelaskan bahwa menggambar adalah : "Drawing is the immediate expression of seeing, thinking and feeling. Drawing is a mirror through wich I understand my place in the word and through which Ican see how I think. "ekspresi langsung dangan cara melihat, berpikir, dan merasakan”. Sedangkan (Sugiyanto 2014 : 4) menjelaskan: "menggambar merupakan bagian manusia yang melibatkan koordinasi antara penglihatan dan dengan gerakan halus tangan".

Berdasarkan penjelasan di atas maka dapat disimpulkan bahwa menggambar adalah keterampilan yang bisa dipelajari oleh setiap orang, terutama yang mempunyai minat menggambar dengan cara memindahkan objek dengan media dua dimensi dengan mengambil objek yang berupa (barang orang atau binatang, tumbu-tumbuhan dan sebagainya).

Menurut (Suherman 2010 : 88) sebagai jenis gambar menjadi beberapa bagian, diantaranya:

1. Menggambar Bentuk

Menurut (Suherman 2010 : 88) menjelaskan: "Menggambar bentuk adalah menggambar dengan meniru objek nyata (realis) yang ada di alam atau buatan.

Sedangkan menurut (Pamandhi 2017 : 88) menjelaskan:"Istilah menggambar Alam Benda sama artinya denga Still Lifedrawing yaitu menggambar objek yang berupa benda-benda disekeliling dan digambar secara langsung berbentuk realis. Bentuk realis tersebut dilihat sesuai dengan arah pandang gambar. Keberhasilan menggambar alam benda adalah ketepatan bentuk yang terlihat dari proporsi, warna, komposisi, posisi gambar benda dan langkah gambar benda".

Berdasarkan penjelasan di atas maka dapat disimpulkan bahwa menggambar bentuk adalah suatu kegiatan menggambar dengan cara meniru objek gambar nyata di atas bidang datar (dua dimensi) berdasarkan unsur-unsur neni rupa.

\section{Menggambar Ekspresi}

Menurut (Suherman 2010 : 88) menjelaskan:"Gambar ekspresi adalah gambar yang dibuat secara bebas berdasar imajinasi, persepsi dan penafsiran penggambar pada objeknya. Gambar ini dicirikan dengan bentuk yang dilebih-lebihkan (didramatisir) atau bahkan bentuk yang direduksi (hanya esensinya). Selain itu penerapan warna pada gambar ekspresif cenderung bebas, bahkan jauh dengan warna aslinya. Seseorang dapat menggambar ekspresi dengan gaya yang bebas dan kadang tidak mengikuti kaidah perspektif dengan gaya yang bebas kadang tidak menikuti kaidah persfektif, bayangan atau skala".

\section{Alat-Alat Menggambar}

Menurut (Suherman 2010 : 22) menjelaskan: alat dan media merupakan faktor utama dan sangat penting dalam menggambar bentuk. Bahan adalah material yang digunakan untuk membuat suatu gambar, sedangkan alat merupakan perkakas yang digunakan untuk membuat suatu gambar.

Adapun alat dan bahan yang digunakan yang biasanya digukanan dalam menggambar bentuk antara lain sebagai berikut:

Kertas Gambar, Pensil AB, H-3H dan 2B-8B, Pensil Warna, Krayon, Cat Air, Cat Poster, Tinta Bak, Penghapus, dan Kuas.

\section{METODE PENELITIAN}

Penelitian ini dilaksanakan di SMP Negeri 1 Simangumban Jl. Sipirok, Tarutung, Kec. Simangumban, Kab. Tapanuli Utara, Prov. Sumut. Adapun alasan penelitian lokasi tersebut karena:

a. Lebih dekat dengan tempat tinggal peneliti sehingga mempermudah peneliti untuk mengumpulkan data.

b. Sekolah memiliki fasilitas yang baik.

c. Belum ada peneliti lain yang meneliti variable yang sama disekolah ini.

Penelitian ini dilaksanakan selama 3 bulan yaitu dimulai pada bulan Juni 2018 s/d bulan Agustus 2018. Adapun populasi dalam penelitian ini yaitu seluruh hasil karya gambar bentuk siswa kelas VII SMP Negeri 1 Simangumban yang berjumlah 124karya.

Peneliti mengambil 25\% dari jumlah populasi. Maka sampel dalam penelitian adalah 30 hasil karya kerajinan tangan siswa. Tehnik pengambilan sampel yang digunakan adalah Random Sampling. Dikatakan simple (sederhana) karena pengambilan anggota sampel dari populasi yang dilakukan secara acak tampa memperhatikan stara yang ada didalam populasi itu.

Teknik pengumpulan data yang digunakan adalah observasi, dan dukomentasi. Metode yang digunakan dalam penelitian ini adalah metode deskriptif. Instrument penelitian yang digunakan yaitu kamera, lembar. Teknik analisis data yang digunakan dalam penelitian ini adalah teknik analisis data deskriptif kualitatif, yaitu mendeskripsikan atau bentuk dari 


\section{Gorga Jurnal Seni Rupa \\ Volume 07 Nomor 02 \\ p-ISSN: 2301-5942 | e-ISSN: 2580-2380}

gambaran yang sejelas-jelasnya mengenai objek yang diteliti dan menilai beberapa besar kemampuan siswa dalam menerapkan prinsip seni rupa dalam menggambar bentuk.

\section{HASIL DAN PEMBAHASAN}

1.Karya Juan Polindo Siagian

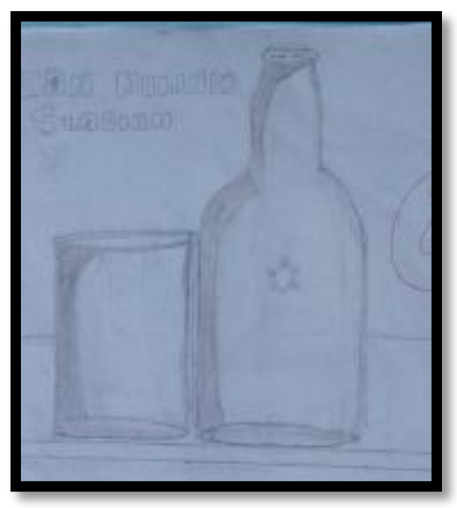

Gambar 1.

Botol dan Gelas 1

(Sumber: Maddina Nainggolan)

Berdasarkan prinsip-prinsip seni rupa, secara keseluruhan karya Juan Polindo Siagian pada prinsip kesatuan memperoleh nilai $=71,65$ dengan kategori $\mathrm{B}$ (Baik) dengan deskripsi pada indikator kesatuan, yaitu karya seni rupa sudah mulai menimbulkan kesatuan garis, bidang dan unsur-unsur rupa lainnya pada karya tersebut.

Pada prinsip proporsi memperoleh nilai $=71,67$ dengan kategori B (Baik) dengan deskripsi pada indikator proporsi, yaitu ukuran gelas dan botol terlihat sebanding, tetapi masih ada kelemahan kerena pangkal leher botol terlihat berbeda antara bagian kiri dan kanan. Untuk itu perlu ketelitian yang lebih lagi saat mengamati objek dalam membuat sketchnya.

Pada prinsip komposisi memperoleh nilai $=71,67$ dengan kategori B (Baik) dengan dekskripsi pada indikator komposisi, yaitu karya tersebut kurang tepat ditengah bidang gambar dan sudut pandang pandang siswa juga mendukung proses dalam menggambar bentuk.

Pada prinsip keseimbangan memperoleh nilai $=73,33$ dengan kategori B (Baik) dengan deskripsi pada indikator keseimbangan, yaitu penataan unsur dengan keseimbang antara bagian yang satu dengan yang lain sudah baik.

Pada prinsip terang gelap memperoleh nilai $=71,65$ dengan kategori B (Baik) dengan deskripsi pada indikator terang gelap, yaitu bayangan/arsiran masih kurang rapi, sehingga objek yang terlihat masih kurang menonjol seperti objek utamanya.

Berdasarkan uraian di atas, nilai tertinggi terletak pada prinsip proporsi, komposisi dan terang gelap dengan nilai $=71,67$ dan jumlah nilai $=359$ dan nilai rata-rata $=72$ maka dapat disimpulkan bahwa dalam menerapkan prinsip-prinsip seni rupa pada karya gambar bentuk Juan Polindo Siagian memiliki kemampuan B (Baik).

\section{Karya Kur Anda Siagian}

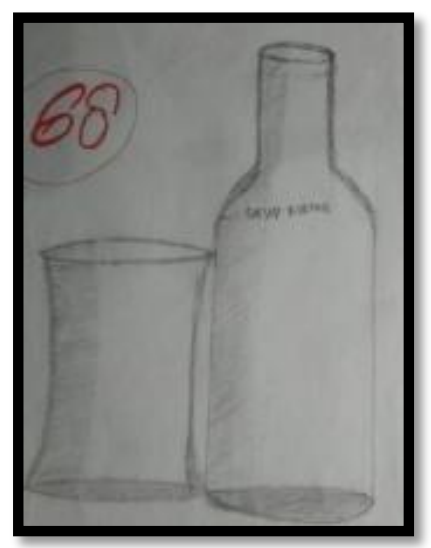

Gambar 2.

Botol dan Gelas 2

(Sumber: Maddina Nainggolan)

Berdasarkan prinsip-prinsip seni rupa, secara keseluruhan karya Kur Anda Siagian pada prinsip kesatuan memperoleh nilai $=70$ dengan kategori $\mathrm{B}$ (Baik) dengan deskripsi pada indikator kesatuan, yaitu karya seni rupa sudah mulai menimbulkan kesatuan garis, bidang dan unsur-unsur rupa lainnya pada karya tersebut.

Pada prinsip proporsi memperoleh nilai $=73,33$ dengan kategori B (Baik), meskipun karya tersebut masih banyak kelemahan. Kesesuaian antara ukuran gelas dan botol terlihat kaku. Untuk itu perlu ketelitian yang lebih lagi saat mengamati objek dalam membuat sketchnya.

Pada prinsip komposisi memperoleh nilai $=73,33$ dengan kategori B (Baik) dengan dekskripsi pada indikator komposisi, yaitu karya tersebut kurang tepat ditengah bidang gambar dan sudut pandang pandang siswa juga mendukung proses dalam menggambar bentuk.

Pada prinsip keseimbangan memperoleh nilai $=66,67$ dengan kategori C (Cukup) dengan deskripsi pada 


\section{Gorga Jurnal Seni Rupa \\ Volume 07 Nomor 02 \\ p-ISSN: 2301-5942 | e-ISSN: 2580-2380}

indikator keseimbangan, yaitu karya tersebut masih banyak kelemahannya, karena penataan unsur dengan keseimbangan belum sesuai.

Pada prinsip terang gelap memperoleh nilai $=65$ dengan kategori C (Cukup Baik) dengan deskripsi pada indikator terang gelap, yaitu bayangan/arsiran masih kurang rapi, sehingga objek yang terlihat kurang menonjol seperti objek utamanya.

Berdasarkan uraian di atas, nilai tertinggi terletak pada prinsip proporsi dan komposisi dengan nilai $=73,33$ dan jumlah nilai $=348,33$ dan nilai rata-rata $=70$ maka dapat disimpulkan bahwa dalam menerapkan prinsip-prinsip seni rupa pada karya gambar bentuk Kur Anda Siagian memiliki kemampuan B (Baik).

\section{Karya Taruna Simanjuntak}

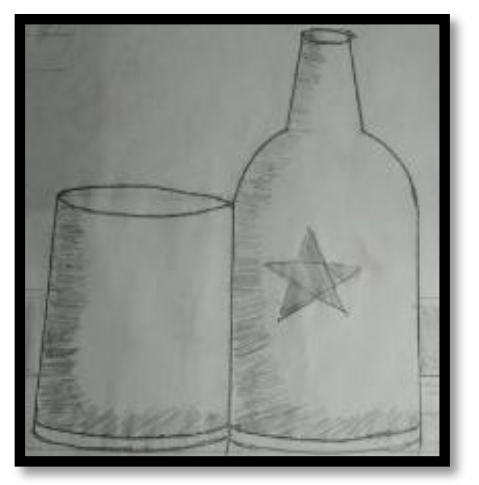

Gambar 3.

Botol dan Gelas 3

(Sumber: Maddina Nainggolan)

Berdasarkan prinsip-prinsip seni rupa, secara keseluruhan karya Taruna Simajuntak pada prinsip kesatuan memperoleh nilai $=70$ dengan kategori $\mathrm{B}$ (Baik) dengan deskripsi pada indikator kesatuan, yaitu karya seni rupa sudah mulai menimbulkan kesatuan garis, bidang dan unsur-unsur rupa lainnya pada karya tersebut.

Pada prinsip proporsi memperoleh nilai $=70$ dengan kategori B (Baik) dengan deskripsi pada indikator proporsi, yaitu ukuran gelas dan botol terlihat tidak sebanding, besar dan leher botol terlihat pendek. Untuk itu perlu ketelitian yang lebih lagi saat mengamati objek dalam membuat sketchnya.

Pada prinsip komposisi memperoleh nilai $=71,67$ dengan kategori B (Baik) dengan dekskripsi pada indikator komposisi, yaitu karya tersebut kurang tepat ditengah bidang gambar dan sudut pandang pandang siswa juga mendukung proses dalam menggambar bentuk.

Pada prinsip keseimbangan memperoleh nilai $=68,33$ dengan kategori C (Cukup) dengan deskripsi pada indikator keseimbangan, yaitu penataan unsur dengan keseimbang antara bagian yang satu dengan yang lain sudah baik.

Pada prinsip terang gelap memperoleh nilai $=70$ dengan kategori B (Baik) dengan deskripsi pada indikator terang gelap, yaitu bayangan/arsiran masih kurang rapi, sehingga objek yang terlihat masih kurang menonjol seperti objek utamanya.

Berdasarkan uraian di atas, nilai tertinggi terletak pada prinsip keseimbangan dengan nilai $=71,67$ dan jumlah nilai $=350$ dan nilai rata-rata $=70$ maka dapat disimpulkan bahwa dalam menerapkan prinsip-prinsip seni rupa pada karya gambarbentuk Taruna Simajuntak memiliki kemampuan B (Baik).

\section{KESIMPULAN DAN SARAN}

Berdasarkan hasil penelitian data yang diperoleh maka dapat disimpulkan bahwa:

1. Prinsip kesatuan memperoleh jumlah nilai = 1911,54 dan rata-rata $(r)=63,71$ dengan kategori C (Cukup). Deskripsi pada indikator kesatuan, yaitu karya seni rupa sudah mulai menimbulkan kesatuan garis, bidang dan unsur-unsur rupa lainnya

2. Prinsip proporsi memperoleh jumlah nilai $=$ 1947,74 dan rata-rata $(r)=65$ dengan kategori $C$ (Cukup). Deskripsi pada indikator proporsi yaitu ukuran gelas dan botol terlihat tidak sebanding, karena objek yang digambar kurang tepat, terkadang kesan yang ditimbulkan terlalu pendek atau terlalu tinggi, atau terlalu gemuk.

3. Prinsip komposisi memperoleh jumlah nilai $=$ 1912,02 dan rata-rata $(r)=64$ dengan kategori $C$ (Cukup). Deskripsi pada indikator komposisi yaitu perbandingan antara objek yang satu dengan yang lainnya kurang tepat ditengah gambar

4. Prinsip keseimbangan memperoleh jumlah nilai $=$ 1776,65 dan rata-rata $(r)=59,22$ dengan kategori C (Cukup). Deskripsi pada indikator keseimbangan yaitu karya tersebut masih banyak kelemahannya, karena penataan unsur dengan keseimbangan belum sesuai.

5. Prinsip terang gelap memperoleh jumlah nilai $=$ 1715,32 dan rata-rata $(r)=57,18$ dengan kategori C (Cukup). Deskripsi pada indikator keseimbangan yaitu karya tersebut masih banyak kelemahan, karena keberanian membuat arsiran sebagian kurang rapi, sebagian tidak ada sehingga gelap 


\section{Gorga Jurnal Seni Rupa \\ Volume 07 Nomor 02 \\ p-ISSN: 2301-5942 | e-ISSN: 2580-2380}

terang tidak terlihat jelas hanya ditandai tekanan warna yang cenderung terang dan terkesan tembus pandang.

Berdasarkan hasil penelitian, maka peneliti memberikan beberapa saran sebagai berikut:

1. Diharapkan kepada siswa SMP Negeri 1 Simangumban agar dalam setiap pembuatan gambar bentuk ataupun menggambar flora, dan fauna menerapkan prinsip-prinsip seni rupa sehingga menghasilkan karya memiliki kualitas yang baik untuk kedepannya.

2. Dalam pembuatan karya gambar bentuk, diharapkan agar siswa lebih dahulu harus mengamati sebelum membuat sketsa, setelah kegiatan yang cukup mantap, mulailah menggambar dengan goresan yang tipis. Hal tersebut dimaksud agar jika terjadi kesalahan gambar dapat diperbaiki dengan mudah. Setelah skets gambar bentuk dipastikan tepat dengan objek yang digambar, perhatikan pencahayaannya dengan melihat dari sisi mana cahaya itu datang, kanan ataupun kiri. Berilah batasan bagian yang terang, bagian yang gelap dan bagian yang setengah gelap.

3. Diharapkan kepada siswa VII SMP Negeri 1 Simangumban agar dalam setiap membuat skets menggunakan pensil HB, karena yang dihasilkan pensil HB tidak terlalu terang sehingga sangat cocok untuk membuat skets awal, sedang untuk membuat gelap terang menggunakan pensil 2B, 3B, 4B, 5B, dan 6B, karena hasilnya lebih pekat sehingga cocok untuk membuat blok/gradasi.

4. Diharapkan hendaknya penelitian ini dilanjutkan dan dikembangkan sehingga dapat memberikan manfaat yang berarti bagi dunia pendidikan dan khususnya siswa kelas VII SMP Negeri 1 Simangumban.

5. Bagi peneliti lain sebagai tambahan literature dalam membuat penelitian selanjutnya.

\section{DAFTAR RUJUKAN}

KBBI. Kamus Besar Bahasa Indonesia. 2014 Jakarta : Gita Media Press.

Mahmud, 2011, Metode Penelitian. Pendidikan. Bandung : CV Pustaka Setia.

Marga Edy Tri. 2017, Mastering Pencil. Surabaya : Genta Group productional.

Masganti, 2017, Psikologi Perkembangan Anak Usia Dini. Depok : Kencana.

Mesra. 2013, Gambar Bentuk 1. Medan : Unimed Press.

Oxford English. 2010, Oxford Dictionary Leaner's New edition. Oxford Universiy Press.
Pamandhi Hadjar, Dkk. 2008, Pendidikan Seni di SD. Jakarta : Universitas Terbuka.

Sembiring Dermawan, Dkk. 2014, Wawasan Seni. Medan : Unimed Press.

Simblet, Sarah, 2014, The Drawing Book.London : Arcturus Publishing.

Sugiyanto. 2014, Seni Budaya. Jakarta : Erlangga.

Suherman Racman, Rizal Ardhya Nugraha, 2010. Seni Rupa. Jakarta : Kementerian Pendidikan Nasional.

Sukimin, dan Sutandur. 2008.Terampil Berkarya Seni Rupa. Solo: Tiga Serangkai.

Sunsanto Mike. 2012.Diksi Rupa. Yogyakart : Dikti Art Lab. 